\title{
The Higher Education System in the Field of Hospitality \& Tourism Management: A Comparative Analysis between Turkey, Switzerland and Germany
}

\author{
Konaklama \& Turizm Yönetimi Alanında Yüksek Ö̆̆retim Sistemi: Türkiye, \\ Isviçre ve Almanya Arasında Karşılaştırmalı Bir Analiz
}

Kadir ÇAKAR*
Beykan ÇİEL

\begin{abstract}
The worldwide increasing need for qualified employment due to an increased level of competition derived from globalization makes not only education systems debatable but also the higher educational systems of countries. One of the important policies for emerging countries is to provide a better higher education system. Necessary steps are taken by governments to increase competitiveness which is regarded as their first priority. One of the significant strategies for emerging countries is to provide a better higher education system by adapting that which developed countries have, and the crucial way of doing so is to improve and ensure the adaptability of the higher education system that considers cultural differences and needs. Therefore it is believed essential that the significance of research being conducted on higher education systems employs a comparative approach. The present study aimed to compare and discuss the field of Tourism Management in the higher education systems of three countries (Turkey, Germany and Switzerland).
\end{abstract}

Keywords: Tourism, Higher Education, Turkey, Germany, Switzerland

$\ddot{O}_{z:}$ Küresel rekabetin artması ile birlikte nitelikli istihdam ihtiyacı dünya genelinde artmakta ve bu durum ülkelerin tüm eğitim sistemleri üzerinde ve yoğun olarak da yükseköğretim sistemleri üzerindeki tartışmaları artırmaktadır. Yükseköğretim kurumlarında kaliteli eğitim öğretim sunma, gelişmekte olan ülkelerin temel ve öncelikli politikaları arasında yer almaktadır. Hükümetlerin önemli önceliklerinden biri, daha iyi bir yükseköğretim sistemiyle ülkelerin rekabet gücünün artırılmasıdır. Eğitim sistemlerinin iyileştirilmesi ve geliştirilmesi için kullanılan önemli stratejilerden bir tanesi gelişmiş ülkelerin eğitim sistemlerini inceleyerek iyi uygulamaları kültürel ihtiyaçlar ve farklılıklara göre uyarlayarak kullanmaktır. Bu nedenle özellikle eğitim sistemlerini karşılaştırmalı olarak inceleyen çalışmaların önemli faydalarının olacağı öngörülmektedir. Bu çalışmada Turizm eğitimi bağlamında üç ülkenin (Türkiye, Almanya ve İsviçre) yükseköğretim sistemleri karşılaştırılmış ve tartışılmıştır.

Anahtar sözcükler: Turizm, Yüksek Öğretim, Türkiye, Almanya, İsviçre

\footnotetext{
* Ph.D. Candidate, Akdeniz University, Institute of Social Sciences, Tourism Faculty, Antalya. kadircakar83@hotmail.com

* Prof. Dr., Akdeniz University, Tourism Faculty, Antalya. beykan@akdeniz.edu.tr
} 


\section{Introduction}

Tourism represents a significant portion of the world economy at macro level, as well as a generator of economic growth in countries at micro level (Padurean \& Maggi, 2009). It is also worth noting that tourism, as an industry, supports and stimulates directly or indirectly a number of related economic sectors. Consequently tourism occupies a considerable space in the agendas of both developed and developing countries and governments pay considerable importance to the tourism sector, which potentially can drive a countries' economy forward. Most importantly, tourism is regarded as an engine fostering a countries' economy both in terms of Gross Domestic Product (GDP) and Gross National Product (GNP) by creating more jobs and infusing the economy with consumer spending. From this point of view, both emerging economies and developed countries are becoming more conversant with the tourism industry which is of increasing importance across the world. Considering the nature of the tourism industry which largely depends upon the service-based, in comparison with the diverse range of other sectors, the quality of the workforce becomes an integral part of the outcome. In addition, in essence, the tourism sector is based upon a labour-intensive and people-centred industry that entails the use of a highly skilled and flexible workforce (Cooper et al. 2005; www.ait.ie/htl/, 15.10.2014).

Tourism plays a crucial role in the stimulation of economies, ensuring growth and creating more jobs in both developing and developed countries. Hence, governments that recognise the economic benefits of tourism, initiate the necessary policy initiatives, as well as introducing incentives for tourism entrepreneurs, as tourism is regarded as the engine of economic growthrecovery (http://media.unwto.org/press-release/2013-12-12/international-tourism-engine-economic-recovery, 10.10.2014). For this reason, the tourism industry demands a highly skilled and well-educated workforce to obtain a particular outcome, to reach the desired objective in terms of the economy. There are three main reasons why higher education systems deserve special attention: a set of general structural changes in higher education, the increasing need for a highly skilled workforce in the tourism industry and a common belief in tourism providing a major source of jobs and careers (Padurean \& Maggi 2011). Today, within the tourism industry, the focal point and the primary consideration of resort communities, business enterprises and establishments is directed to the recruitment and retention of a highly qualified workforce, alongside the flexibility of their employees. This study presents a different comparative perspective on the higher education systems of Turkey, Germany and Switzerland providing information concerning each national system.

\section{The Turkish Education System in Turkey}

The modern education process of Turkey is said to have begun in the 1920's with the foundation of the Turkish Republic. Since the foundation of the Turkish Republic related legislative regulations in terms of education were initiated by Turkish governments. In this context, the central role of the Ministry of National Education directly controls all educational activities. Its primary purpose is increasing the quality of education at all levels and is responsible for the organization of each level of education in Turkey. The Turkish educational system is divided into four main categories: Pre-School, Primary and Lower Secondary, Upper Secondary and Higher Education. The length of compulsory education in Turkey has recently been transformed into $4+4+4$ or 12 years, consisting of three phases. The higher education system of Turkey can be divided into two parts; the state and the private universities. Both types of universities are recognized by the Government, and they are legally bound to the Council of Higher Education (https://webgate.ec.europa.eu/fpfis/mwikis/eurydice/index.php/Turkey:Overview, 11.10.2014). 
Within this legal context, the Council of Higher Education is mainly responsible for the higher education system that controls and directs the majority of higher education institutions. It also supports research and development initiatives in the achievement of academic objectives. Moreover, the Council of Higher Education financially supports and provides assistance to undergraduates through a wide range of payment options for their studies through the help provided by the Government's education loans. Following the 1980's intervention, the Council of Higher Education obtained a much tighter regulatory control over the higher education system. Further, the transformation of the Turkish higher education system sustained its potential for growth in providing strong articulation within internationally recognized systems, in particular through the Bologna Process. Increasing efficiency in terms of the higher education system, Turkey adapted the Bologna Process thereby improving its own system. In that sense, researchers from a wide range of fields and members of the academic community are supported and stimulated by the Council of Higher Education and Government in its support for their scientific research. Today, the Council of Higher Education is highly motivated and much more research-oriented than in the past. In consequence today the Council of Higher Education is focusing upon a new road map in the light of the 2023 goals and global dynamics for the modernization of the Turkish higher education system, as well as the realization of a greater quality oriented higher education system within a globalized world (www.yok.gov.tr, 25.10.2014).

The start of studies in the field of tourism education began in the 1950's in Turkey. Subsequently, many institutions began establishing and promoting tourism education at all levels. Several institutions that provide tourism vocational training were established by public institutions and a number of institutions were founded by both the public and the private sector to increase the quality of tourism education and to meet the needs of the expanding tourism industry. Tourism education is divided into two basic categories: theoretical and practical (Soybalı \& Bayraktaroğlu 2013).

When the tourism education system in Turkey is considered, one finds it heavily depends upon two fundamental structures, which can be evaluated under both diffused and organized educational systems. The diffused education system is organized by the Ministry of Culture and Tourism, TUREM (Tourism Education Center), and the MEB (Ministry of Education). Organized education is implemented by the Council of Higher Education together with the MEB. Table 4 delineates the education types within Turkey's Tourism Education System (Güzeller et al. 2009).

Within the context of the diffused tourism education system, professional tourist guide courses are provided by the Ministry of Culture and Tourism. Further, the profession of tourist guide admission tests, certification programs, foreign language tests and practice trips are also organized by the tourist guides associations under the supervision and the control of the Ministry of Culture and Tourism. The MEB itself also organizes and implements education by providing food and beverage service courses which provide people with the skills necessary to enter the tourism sector. Similarly, in order to meet the needs of the tourism industry the TUREM (Tourism Education Center) has been introduced by the MEB. The primary aim and distinguishing feature of TUREM is to develop highly-skilled employees and to create high quality human resources for the tourism sector, these being a key driving factor in the critical success of the tourism industry (http://aregem.kulturturizm.gov.tr/TR,51184/turist-rehberligi. html, 26.10.2014) 
Table 1: Turkey's Tourism Education System

\begin{tabular}{|c|c|}
\hline Diffused Education & Organized Education \\
\hline $\begin{array}{l}\text { MINISTRY OF CULTURE AND TOURISM } \\
\text { Professional Tourist Guide Courses }\end{array}$ & $\begin{array}{l}\text { MEB (Ministry of Education) } \\
\text { Anatolian Hotel and Tourism Vocational School) }\end{array}$ \\
\hline $\begin{array}{l}\text { TUREM (Tourism Education Center) } \\
\text { Open Education Faculty, Tourism Education via } \\
\text { TV) }\end{array}$ & $\begin{array}{l}\text { YÖK (Council of Higher Education) } \\
2 \text { Years associate degree programs giving tourism } \\
\text { education at Vocational Schools }\end{array}$ \\
\hline $\begin{array}{l}\text { MEB (Ministry of Education) } \\
\text { Food and Beverage Services Apprenticeship } \\
\text { Courses }\end{array}$ & $\begin{array}{l}4 \text { Years bachelor's degree programs in Tourism } \\
\text { and Hotel Administration } \\
\text { Graduate programs } 2 \text { years master and at least } 3 \\
\text { years of postgraduate education. }\end{array}$ \\
\hline
\end{tabular}

Source: Güzeller et al. 2009, 8

The MEB and the Council of Higher Education are responsible for the educational organization. Education in tourism is offered at high school, those schools termed the Anatolian Hotel and Tourism Vocational School, which is organized and coordinated by the MEB. These vocational schools offer tourism education at a basic level and include learning a foreign language. Overall, the length of the period of education at the Anatolian Hotel and Tourism Vocational Schools is four years. The first year consists of preparatory classes in which the students are obliged to learn a foreign language. The remaining three years provide these students with an education in tourism which is combined with practical work experience within the tourism industry. According to the National Education Statistics for the educational year 2013/14, the number of Anatolian Vocational High Schools for Hotel Management and Tourism consisted of 135 and the total number of students was 36,259 (National Education Statistics Formal Education, 2013/'14; http://www.meb.gov.tr/,19.11.2014). There are two types of higher education institutions that offer tourism education in Turkey: a two years associate degree program providing tourism education at vocational schools, and there is a four years bachelor's degree program offering tourism and hotel administration programs. The Council of Higher Education is responsible for the implementation, organization and coordination of these. In addition, additional higher level educational opportunities are offered in the form of a two year Masters program and a three year $\mathrm{PhD}$ program. In some universities, the duration of the $\mathrm{PhD}$ is four years, rather than the three years in the field of tourism management. Tourism education is offered at higher level in three stages: Bachelor, Master and $\mathrm{PhD}$. There are 37 programs at the Masters level and 17 programs at the $\mathrm{PhD}$ level that currently offer at postgraduate level tourism education in Turkey (Güzeller et al. 2009; Güzel 2014).

\section{The Tourism Education System of Germany}

In Germany, unlike the structure in Turkey, the education system is implemented under two umbrellas. Due to the Federal structure of the country, the education system is the responsibility of both the German Federation and of the Länder (States). The responsibilities of the Federal Government in terms of education, are those described in the German constitution. In this 
context, providing the constitution provides legislative powers to the Federation, the Länder can possess their legislative power. Overall, in the Federal Republic of Germany the educational system is the responsibility of the Länder which organize and carry it out. Moreover, the constitution enables cooperation between the Federation and the States in respect to joint tasks undertaken in the area of education https://webgate.ec.europa.eu/fpfis/mwikis/eurydice/index. php/Germany: Overview, 11.10.2014).

Table 2: Number of Undergraduates According to Field of Study

\begin{tabular}{l|c|c}
\hline Field of Study & Total Number of Students & $\begin{array}{c}\text { Number of Tertiary } \\
\text { Enrolments }\end{array}$ \\
\hline Tourism \& Hotel Management & 2356 & 2302 \\
\hline Tourism Management & 3151 & 2788 \\
\hline Hospitality Management & 1835 & 1835 \\
\hline Tourism \& Travel & 394 & 389 \\
\hline Tourism Guidance & 595 & 587 \\
\hline Travel \& Tourism Guidance & & 343 \\
\hline Food \& Beverage & 439 & 305 \\
\hline Management & 305 & 539 \\
\hline Gastronomy \& Culinary Arts & 714 & 101 \\
\hline Gastronomy & & 89 \\
\hline Recreation Management & 148 & 631 \\
\hline Hotel Management & 89 & \\
\hline TOTAL & 64 & \\
\hline & & \\
\hline
\end{tabular}

Source: www.osym.gov.tr, 23.10.2014

"Those universities that offer Tourism Education at a higher level, such as in the Turkish Republic of Northern Cyprus and in Azerbaijan which are recognized by the Council of Higher Education including the Faculty of Open Education University have been excluded from the above list.

In addition to the abovementioned legalities, in 1997, The Lisbon Convention on the Recognition of Qualifications Concerning Higher Education in the European Union, initiated an act that provided a formal structure which introduced a number of processes in terms of the Higher Education Systems within communities. According to this Convention, a formal structure for the acceptance and equivalency of higher education programs and qualifications created the mutual recognition principle across Europe. This initiative provided member states, as well as candidate countries, for the adoption of the new higher education system to the EU (Lominé, 2003; http://eacea.ec.europa.eu/education/eurydice/documents/all_publications.pdf. 30.10.2014). 
The length of compulsory general education consists of ten years, while the subsequent period of part-time compulsory education, which means compulsory vocational education, lasts for three years. Furthermore, within the context of the dual system (duales system), study courses are offered at vocational schools, and the pupils are requested to employ their theoretical knowledge in companies by means of vocational training. In this system, in study institutions, this is termed Berufsakademi. Academic training is combined with practical experience within a company (http://www.kmk.org/fileadmin/doc/Dokumentation/Bildungswesen_en_pdfs/en-2014. pdf, 29.10.2014).

The German Higher Education System can be divided into two main categories. The first category is the first cycle program which contains the Bachelors' Diploma which provides a first qualification in a profession. The second category consists of the postgraduate programs. The German Higher Education system is divided into: universities, university of applied sciences and colleges of art and music. Most of the higher education institutions are financially supported by the state and therefore the state organize these institutions within the scope of its regulatory framework. However, many higher education institutions are administered by the Protestant and Catholic Churches, as also by private institutions that are recognized by the state. The majority of private institutions are universities of applied sciences whose primary purpose is to provide practical work and applications. Many universities offer education within a particular field, while some institutions primarily focus on providing a wide range of subjects. There are 124 institutions and universities that are currently offering tourism education at a higher level within Germany. Given the German Tourism Higher Education structure, the number of fields of study can be subdivided into several areas or branches: Tourism, Tourism and Travel Management, Tourism Industry, Tourism and Destination Development, International Hospitality Management, International Hotel Management and International Tourism Studies. However, some particular fields are subcategorized under these main fields which indicate more specific fields such as Service Management, Transport Management, Aviation Management, Health Tourism, Cruise Tourism Management, Geography, Landscape Development and Nature Conservation and Innovations and Entrepreneurship in Tourism (http://www.hochschulkompass.de/en/higher-education-institutions.html, 13.10.2014). Financial aid for Higher Education is provided in several different ways in Germany. It is mainly endorsed by the BAföG (Bundesausbildungsförderungsgesetz-Federal Training Assistance Act) that is an institution provided by the state (http://www.hochschulkompass.de/en/higher-educationinstitutions.html, 13.10.2014). Another institution is the DAAD (Deutscher Akademischer Austausch Dienst-German Academic Exchange Service) that financially supports foreign researchers and people who are willing to study in Germany at the level of higher education. The DAAD stimulates postgraduates, researchers and academics by ensuring financial support and close cooperation. One of the primary aims of the DAAD is to increase the attractiveness of German Higher Education, science and research (https:/www.daad.de/hochschulen/en/ 13.10.2014). Furthermore, German higher education is less hiearchical when compared to other European countries (Münkler 2013).

\section{The Tourism Education System of Switzerland}

Tourism, a vibrant industry in Switzerland has great importance in economic terms for the Swiss government. As is the case in Turkey, tourism is considered one of the most important economic sectors for Switzerland, in terms of its share of gross value added and for employment. From the statistical data provided by the Bundesamt für Statistik (Swiss Federal Statistical Office) the domestic total gross value added contributed 614.153 million CHF to the 
economy in the second quarter of the 2013 fiscal year and tourism contribution to gross value added was recorded as 16.205 million CHF. In this same period, within the tourism context the share of gross value added contributed 2,6 \% while the share of the employment rate was 4,3\% (Swiss Federal Statistical Office, 2015).

The Swiss education system shares with Germany, some similarities in its essential form. The individual cantons (States) are mainly responsible for the organization and implementation of education at all level except for that at universities. Overall the Swiss education system has been configured and shaped by the federalism that it displays within the scope of decentralization. In this respect, individual cantons are mainly responsible for the education system unless the federal constitution empowers or grants authorization the cantons and confederation to use their legislative power. In some cases, collaborative initiatives can be taken, such as coordination and close cooperation in terms of compulsory education and higher education, wherever the federal constitution stipulates an obligation to the cantons. In this manner, the cantons may find a solution between each other as and when required (https:// webgate.ec.europa.eu/fpfis/mwikis/eurydice/ index.php/Switzerland: Overview, 11.10.2014).

There are a total of 26 cantons whose structure comprises federal Switzerland. The Cantons are mainly responsible for the education system unless the federal constitution surrenders the legislative power to the confederation. The Swiss education system contains the following six major areas: pre-school, primary school level, lower-secondary education, upper secondary education, tertiary-level education and continuing education and vocational training. The cantons and the municipalities are the responsible for compulsory education, while the confederation is responsible for the post-compulsory education system in respect to Baccalaureate schools, vocational and professional education and training and tertiary-level A institutions. The cantons and the confederation can perform joint tasks in terms of education through sharing responsibility for the public education system. Considering the federal and the cantonal structure of the Switzerland, each canton possesses its own school and education system, and each cantons' education system is organized by the minister of education who is main responsible for education. The State Secretariat for Education, Research and Innovation (SERI) is the federal government's competent agency at both national and international levels which is responsible for the implementation of education, research and innovation policy. The duration of compulsory education in Switzerland is for a period of at least nine years which is divided into two parts: the primary school level and the lower-secondary education. In most cantons, the primary school level continues for six years and the lower-secondary education continues for three years (http://www.edk.ch/dyn/11586.php, 05.11.2014; https://webgate.ec. europa.eu/fpfis/mwikis/eurydice/index.php/Switzerland:Overview,11.10.2014;http://swisseduca tion.educa.ch/en/swiss-education-system-3, 05.11.2014).

Vocational education and training programs (VET) enable people to obtain the necessary skills and knowledge which are required to qualify for finding a job. There are three levels of VET programs in Switzerland: two-year, three-year and four-year. However, for Apprenticeship positions, there are there are two dimensional Apprentice types. One of these is provided by the host companies ensuring Apprenticeship positions are generated on the supply side. On the other hand, on the demand side, young people seek Apprenticeship positions. In this context, the State has an intermediary role which endorses counseling guide to the young people to help them achieve their career objective and create the best Apprenticeship opportunities for the host companies (http://www.sbfi.admin.ch/berufsbildung/01587/index.html?lang=en, 05.11.2014). 
The Swiss higher education structure can be divided into two types. The first type comprises the universities. The second type refers to the University of Applied Sciences (UAS). Universities focus on providing education and implementing research whilst the University of Applied Sciences tends to provide students with a practical-oriented education. Both types of institutions have the same status (http://www.sbfi.admin.ch/themen/hochschulen/index.html? lang=en, 05.11.2014). In addition to the several universities and institutions that are financially endorsed by the State, there are 12 doctoral/research universities, eight universities of applied sciences and arts, and 20 universities of teacher education. In the Swiss higher education system, studies are firmly grounded in the three-tiered concept: Bachelor, Master and Doctoral. After 2006, the Switzerland education system was transformed in accordance with the Bologna Process. Alongside the Bachelor, Master, and $\mathrm{PhD}$ education, a Master of Advanced Studies (MAS) is also offered. However, obtaining a MAS does not ensure that these candidates will be admitted to a PhD degree program (Studying in Switzerland, 2014; http://www.studyingin switzerland.ch/studying-in-switzerland.htm, 07.11.2014; Higher Education and Research in Switzerland, 2013; http://www.sbfi.admin.ch/themen/01367/index.html?lang=en, 07.11.2014)

Table 3: Swiss Institutions offering Hospitality \& Tourism Management at a Higher Level

\begin{tabular}{|c|c|c|c|c|c|}
\hline $\begin{array}{l}\text { Name of the University/ } \\
\text { Institutions }\end{array}$ & Bachelor & Master & $\mathrm{PhD}$ & Location & Designation \\
\hline École Hôtelière de Lausanne & $\sqrt{ }$ & $\sqrt{ }$ & $\sqrt{ }$ & Lausanne & UAS \\
\hline${ }^{* * *}$ Les Roches-Gruyère & $\sqrt{ }$ & $\sqrt{ }$ & - & Bluche \& Bulle & UAS \\
\hline $\begin{array}{l}\text { Swiss Hotel Management } \\
\text { School }\end{array}$ & $\sqrt{ }$ & $\sqrt{ }$ & - & Caux/Montreux & UAS \\
\hline $\begin{array}{l}\text { Business \& Hotel Management } \\
\text { School }\end{array}$ & $\sqrt{ }$ & $\sqrt{ }$ & - & Luzern & UAS \\
\hline IMI University & $\sqrt{ }$ & $\sqrt{ }$ & - & Luzern & UAS \\
\hline César Ritz Colleges & $\sqrt{ }$ & $\sqrt{ }$ & - & $\begin{array}{l}\text { Lucerne/Brig/Le } \\
\text { Bouveret }\end{array}$ & UAS \\
\hline The University of Lugano & - & $\sqrt{ }$ & - & Lugano & University \\
\hline $\begin{array}{l}\text { European University Business } \\
\text { School }\end{array}$ & $\sqrt{ }$ & $\sqrt{ }$ & - & Montreux/Geneva & University \\
\hline $\begin{array}{l}* * \text { University of Applied } \\
\text { Sciences Chur }\end{array}$ & $\sqrt{ }$ & $\sqrt{ }$ & - & Chur & UAS \\
\hline The Luzern Business School & $\sqrt{ }$ & $\sqrt{ }$ & - & Luzern & UAS \\
\hline *IUKB & - & $\sqrt{ }$ & $\sqrt{ }$ & Sion & University \\
\hline $\begin{array}{l}* * * * \text { Glion Institute of Higher } \\
\text { Education }\end{array}$ & $\sqrt{ }$ & $\sqrt{ }$ & - & Glion/Bulle & University \\
\hline
\end{tabular}

Source: The information in the table above generated by the authors using data extracted from "The Swiss Conference of Cantonal Ministers of Education (EDK)" and "Eurodesk Switzerland" (eurodeskch@eurodesk.eu, 16.10.2014; The Swiss Conference of Cantonal Ministers of Education (EDK), 06.11.2014).

* The Institut Universitaire Kurt Bösch offers a PhD in the field of tourism education in cooperation with University of Lausanne. 


\section{${ }^{* *}$ UAS: University of Applied Sciences.}

${ }^{* * *}$ This is a private institution which is recognized by the confederation.

**** Glion Institute of Higher Education has two campuses in Switzerland and one campus in London.

The Swiss higher educational system in the field of hospitality and tourism management courses are offered by institutions which concentrate on providing undergraduates and graduates with practical work experience within the tourism industry. For this reason, the majority of institutions and the University of Applied Sciences ensure students internship opportunities, so they can obtain practical experience within the industry. Courses are commonly offered at the bachelor and masters level, fostering the students practical work experience within the hospitality and tourism sector. In this respect, $\mathrm{PhD}$ opportunities remain rather limited when compared to bachelor and masters programs. Overall, the majority of institutions, universities and the University of Applied Sciences secure undergraduate and graduate internship opportunities to ensure that students have valuable practical experience bringing them together with experts within the field of tourism. In addition, some institutions or universities that offer hospitality and tourism education, require students to have had work experience as a prerequisite for admission into a hospitality and tourism degree program.

Table 4: Top 10 International Hospitality Management Schools in the World for an International Career

\begin{tabular}{l|l|c} 
Rank & Institution & Country \\
\hline 1 & Ecole Hôtelière de Lausanne & Switzerland \\
\hline $2^{*}$ & Les Roches International School of Hotel Management, Bluche & Switzerland \\
\hline $2^{*}$ & Glion Institute of Higher Education, Glion \& Bulle & Switzerland \\
\hline $2^{*}$ & Cornell University & USA \\
\hline 5 & Hotelschool The Hague & Netherlands \\
\hline 6 & Les Roches International School of Hotel Hotel Management, Marbella & Spain \\
\hline 7 & Hotel School Vatel & France \\
\hline 8 & Oxford Brookes University & United \\
\hline 9 & César Ritz Colleges, Le Bouveret, Brig & Switzerland \\
\hline 10 & Ecole Hôtelière de Genėve & Switzerland
\end{tabular}

Source: http://m.tourism-review.com/travel-tourism-magazine-top-10-hotel-schools-in-the-world-article 1565\#.VLmBCv1tHvE.twitter, 2011.

*Les Roches International School of hotel Management, Glion Institute of Higher Education and Cornell University are tied for second position.

${ }^{* *}$ Based on the frequency of school selection by hospitality industry hiring managers of 5 star hotels (sample size $=181$ respondents).

Further, Table 4 presents precious statistical data derived from a survey conducted in 2010 which indicates the top 10 international hospitality management schools worldwide. Considering the results of this survey one can assume that the nature of the Swiss higher 
education system in the field of Hospitality Management has enabled the Swiss to take the lead position in the list (Survey: Swiss Hotel Schools Are The Best, 2011). In assessing Table, 5 Swiss universities are ranked amongst world's leading hospitality management schools. In this classification, no University or Institution providing Hospitality and Hotel Management education from Germany or Turkey is recorded, while Switzerland emerges as a leader among world's top 10 international universities. The main reason why none of the German universities finds a place in this list is that Germany is a country which is described as a strong exporting country of researchers and students after obtaining their graduation (Münkler, 2013). Similarly, Turkish Higher Education system in the field of Hospitality and Tourism Management seems to be very poorly equipped to provide an outstanding level of tourism education when compared to Switzerland and Germany and shows the needs of the hospitality sector are not fully met.

\section{Conclusions}

The tourism education system of Turkey is characterized by two main types: diffused and organized education systems. The Ministry of Culture and Tourism, TUREM (Tourism Education Center), and MEB (Ministry of Education) organize and implement diffused education, while the Council of Higher Education (YÖK) is responsible for the higher tourism education system. Given the higher tourism education system of Turkey, there is a tendency for those institutions which offer a four years bachelor's degree program in Tourism and Hotel Administration, to move it from the Faculty of Economics and Administrative Sciences and incorporate it within the Faculty of Tourism.

Considering the nature of the educational system of the Federal Republic of Germany, one can clearly assert that the constitution takes precedence over both the Federal and the Länder's law and that the Länder can use their legislative power derived from basic law. In assessing the structure of the higher tourism education system of Turkey, one can conclude that courses are offered with a narrower range of subjects under the main fields, when compared to the courses offered in the higher tourism education system of Germany. In other words the courses offered are categorized in a general manner in the higher tourism education system of Turkey; while in Germany within the tourism education system there are the new sub-branches, as well as programs subdivided into sub-divisions under the main branches.

The main characteristic of Switzerland's higher education structure is that the courses that are offered by institutions are designed to provide undergraduates and graduates with practical work experience within the tourism industry together with theoretical knowledge. Therefore, most of institutions and the University of Applied Sciences secure for undergraduates and graduates internship opportunities to provide better real work experience within the tourism sector. Another significant point is that the courses are offered largely at Bachelor and Master's level, accelerating students practical work experience within the hospitality sector. In this sense, the $\mathrm{PhD}$ program opportunities in Switzerland remain rather less as a proportion, when compared to Bachelor and Master Programs. Consequently, the institutions, universities and the University of Applied Sciences offering hospitality and tourism education, concentrate on preparing undergraduates and graduates for the professional work environment through work experience within the industry network. 
Table 5: Comparative Context of the Higher Education Systems of Turkey, Germany and Switzerland

\begin{tabular}{|c|c|c|c|c|c|}
\hline Countries & Part Time & Full Time & $\begin{array}{l}\text { Scope of Higher } \\
\text { Education } \\
\text { System }\end{array}$ & $\begin{array}{l}\text { The Legal } \\
\text { Context of the } \\
\text { Higher Education } \\
\text { System }\end{array}$ & $\begin{array}{l}\text { Organization, } \\
\text { Coordination, and } \\
\text { Implementation } \\
\text { Body of Higher } \\
\text { Education System }\end{array}$ \\
\hline Turkey & $\begin{array}{l}\text { Not } \\
\text { Applicable }\end{array}$ & Applicable & Centralization & Monist $^{*}$ & $\begin{array}{l}\text { Council of Higher } \\
\text { Education (YÖK) }\end{array}$ \\
\hline Germany & Applicable & Applicable & Decentralization & Dualist $^{* *}$ & $\begin{array}{l}\text { Bundesausbildung } \\
\text { sförderungsgesetz } \\
\text {-Federal Training } \\
\text { Assistance Act } \\
\text { (BAföG) }\end{array}$ \\
\hline Switzerland & Applicable & Applicable & Decentralization & Dualist & $\begin{array}{l}\text { The State } \\
\text { Secretariat for } \\
\text { Education, } \\
\text { Research and } \\
\text { Innovation } \\
\text { (SERI) \& Swiss } \\
\text { Conference of } \\
\text { Cantonal } \\
\text { Ministers of } \\
\text { Education (EDK) }\end{array}$ \\
\hline
\end{tabular}

Source: Authors' Compilation

* The higher education system is organized as a unitary form which is organized and coordinated by a single body

** The higher education system is under the responsibility of both the Federation and the States

\section{Acknowledgments}

The authors would like to express their great gratitude to "The Swiss Conference of Cantonal Ministers of Education (EDK)", "Eurodesk Switzerland" and the "Swiss Federal Statistical Office" for their kind assistance and cooperation which provided the authors with invaluable information during the period in which this research was written. 


\section{REFERENCES}

Cooper C. $\left(2005^{3}\right)$. "An Introduction to Tourism". Eds. Cooper C., Fletcher J., Fyall A., Gilberth D., Wanhill S. Tourism-Principles and Practice. Prentice Hall 2005.

Güzel Ö. S. (2014). "Turizm Alanında Doktora Eğitimi Alan Öğrencilerin Memnuniyetlerinin Belirlenmesine Yönelik Bir Araştırma”. Gazi Üniversitesi Turizm Fakültesi 15. Ulusal Turizm Kongresi, 1316 December: Engelsiz Turizm (2014) 1414-1421.

Güzeller O. C., Yıldız S. \& Sonuç N. (2009). "Comparison of Tourism Education Programs in Turkey and Greece and Future Challenges". TURIZAM 13/1 (2009) 5-16.

Higher Education and Research in Switzerland. (2013). Federal Department of Economic Affairs, Education and Research (EAER), State Secretariat for Education, Research and Innovation. Switzerland 2013. Source: http://www.sbfi.admin.ch/themen/01367/index.html?lang=en. Accessed: 07.11.2014.

Lominé L. L. (2003). "Hospitality, Leisure, Sport and Tourism in Higher Education in France". Journal of Hospitality, Leisure, Sport and Tourism Education 2/1 (2003) 105-112.

Münkler H. (2013). Centres of Learning: Universities in the Global Knowledge Society. Source: https://www.deutschland.de/en/topic/knowledge/higher-education-research/centres-of-learning. Accessed:15.07.2015.

National Education Statistics Formal Education. (2013/14). Republic of Turkey Ministry of National Education, A Publication of Official Statistics Programme. Available at: http://www.meb.gov.tr. Accessed: 19.11.2014.

Padurean L. \& Maggi R. (2009). "Higher Tourism Education in English-Where and Why?". Tourism Review 64/11 (2009) 48-58.

Padurean L. \& Maggi R. (2011). "TEFI Values in Tourism Education: A Comparative Analysis". Journal of Teaching in Travel \& Tourism 11 (2011) 24-37.

Soybalı H. H. \& Bayraktaroğlu E. (2013). “Türkiye'de Lisans Düzeyinde Turizm Eğitimi Veren Kurumların Uygulama Olanaklarının Değerlendirilmesi Üzerine Bir Araştırma [A Study on the Evoluation of Practicing Assets of Undergraduate Tourism Education Institutions in Turkey]". Anatolia: Turizm Araştırmaları Dergisi 24/2 (2013) 185-199.

Studying in Switzerland. (2014). Swissuniversities Publication. Eds. Amherd L., Tafani T., Schalbetter E., Galliker J. M. \& Glauser D. Bern 2014. Available at: http://www.studyinginswitzerland.ch/ studying-in-switzerland.htm. Source: 07.11.2014.

Survey: Swiss Hotel Schools Are The Best. (2011). Tourism Review Online Magazine 7. Source: $\mathrm{http}: / / \mathrm{m}$.tourism-review.com/travel-tourism-magazine-top-10-hotel-schools-in-the-worldarticle1565\#.VLmBCv1tHvE.twitter. Accessed: 09.08.2015.

Swiss Federal Statistical Office. (2013). Tourism Share of Gross Value Added and Employment. Source: http://www.bfs.admin.ch/bfs/portal/de/index/themen/10/02/blank/key/01.html. Accessed: 13.07.2015.

UNWTO Tourism Highlights. (2014 Edition). Source: http://dtxtq4w60xqpw.cloudfront.net/sites/all/ files/pdf/unwto_highlights14_en_hr_0.pdf, Accessed: 10.10.2014.

\section{Electronic Sources}

www.yok.gov.tr

http://www.meb.gov.tr/

http://www.kulturturizm.gov.tr/

https://www.daad.de/hochschulen/en/

http://www.ait.ie/htl/

http://eacea.ec.europa.eu/education/eurydice/index_en.php

http://www.kmk.org/

http://www.hochschulkompass.de/

http://www.edk.ch/dyn/11586.php 
http://www.sbfi.admin.ch/themen/01366/01380/02175/index.html?lang=en eurodeskch@eurodesk.eu http://www.studyinginswitzerland.ch/ www.tourism-review.com 
